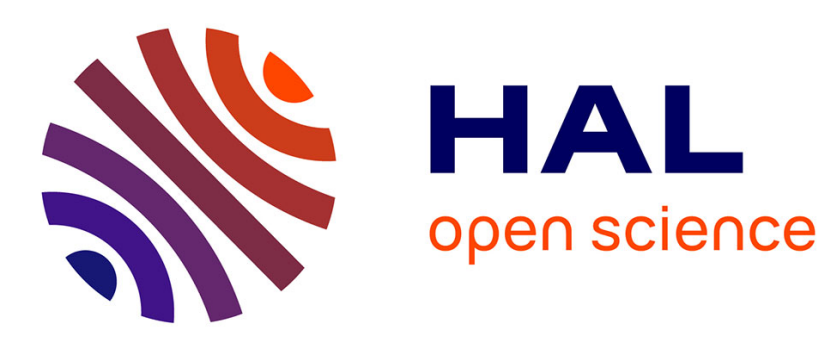

\title{
Convergent readings of groundwater governance? Engaging exchanges between different research perspectives
}

Nicolas Faysse, Olivier Petit

\section{To cite this version:}

Nicolas Faysse, Olivier Petit. Convergent readings of groundwater governance? Engaging exchanges between different research perspectives. 2012. cirad-00872495

\section{HAL Id: cirad-00872495 http://hal.cirad.fr/cirad-00872495}

Preprint submitted on 13 Oct 2013

HAL is a multi-disciplinary open access archive for the deposit and dissemination of scientific research documents, whether they are published or not. The documents may come from teaching and research institutions in France or abroad, or from public or private research centers.
L'archive ouverte pluridisciplinaire HAL, est destinée au dépôt et à la diffusion de documents scientifiques de niveau recherche, publiés ou non, émanant des établissements d'enseignement et de recherche français ou étrangers, des laboratoires publics ou privés. 


\title{
CONVERGENT READINGS OF GROUNDWATER GOVERNANCE? ENGAGING EXCHANGES BETWEEN DIFFERENT RESEARCH PERSPECTIVES
}

\author{
Nicolas Faysse ${ }^{1}$, Olivier Petit ${ }^{2}$ \\ ${ }^{1}$ CIRAD, G-EAU Research Unit, National Agricultural College of Meknès (Morocco). faysse@cirad.fr. \\ ${ }^{2}$ Université d'Artois \& Centre Lillois d'Etudes et Recherches Sociologiques et Economiques (CLERSE, \\ UMR 8019 CNRS-Lille1), Arras (France). olivier.petit@univ-artois.fr.
}

This is the pre-peer reviewed version of the article with the same title, which has been published in final form at http://onlinelibrary.wiley.com/doi/10.1002/ird.1654/abstract.

\begin{abstract}
In the last 50 years, the study of groundwater governance has given birth to rich and differentiated analytical approaches. This article proposes an exchange between the main heuristic viewpoints, results and theses of three approaches which studied groundwater governance: the study of groundwater governance as collective action initiated by E. Ostrom, the analysis made by T. Shah on informal groundwater economies and the works of A. Prakash, A. Mukherji and T. Birkenholtz drawing on political ecology. The aquifers on which each approach originally built its analysis played a key role in the design of analytical frameworks which, in the case of the first two approaches, were later applied to a much larger set of cases. The three approaches share many commonalities in their heuristic methods. However, they differ in the content of governance systems recommended to achieve sustainable groundwater use, and especially in the benefits of involving water users in the implementation of governance. Therefore, they also differ on what should be the focus of academic analyses. It is thus of interest to organize joint readings of cases of groundwater governance and to discuss the contents of research programs able to provide fruitful analyses of these cases, based on local specificities.
\end{abstract}

Key words: demand management, heuristic viewpoint, groundwater governance

\section{RESUME}

Durant les 50 dernières années, l'étude de la gouvernance des eaux souterraines a donné naissance à des approches analytiques riches et différenciées. L'article propose un échange entre les principaux points de vue heuristiques, les résultats et les thèses de trois approches qui ont étudiés la gouvernance des eaux souterraines: l'étude de la gouvernance des eaux souterraines vue comme action collective telle qu'initiée par E. Ostrom, l'analyse faite par T. Shah des secteurs économiques informels permis par l'usage des eaux souterraines et les travaux de A. Prakash, A. Mukherji et T. Birkenholtz qui se sont inspirés de l'écologie politique. Les aquifères pour lesquels chaque approche a été initialement conçue ont joué un rôle capital dans la conception d'un cadre d'analyse qui, pour les deux premières approches, a ensuite été mis en œuvre dans un grand nombre de cas. Les trois approches partagent de nombreux éléments de leurs méthodes heuristiques. Elles diffèrent cependant dans le contenu des systèmes de gouvernance préconisés pour permettre un usage durable des eaux souterraines, et en particulier en ce qui concerne le bénéfice d'impliquer les usagers dans la mise en œuvre de la gouvernance. De ce fait, ces approches diffèrent aussi sur ce que devrait être au cœur d'analyses académiques. II serait ainsi intéressant d'organiser des lectures communes de cas de gouvernance des eaux souterraines et de discuter du contenu de programmes 
de recherche qui permettent des analyses fructueuses de tels cas, en prenant en compte les spécificités locales.

Mots clés: gestion de la demande, point de vue heuristique, gouvernance des eaux souterraines

\section{INTRODUCTION}

Groundwater has a particular position in studies of natural resources management. While the "social dilemmas" (Ostrom, 2007) inherent in the use of groundwater resources are broadly similar around the world, the contexts of the definition and implementation of institutions (understood here broadly as formal and informal rules and social norms) to face these dilemmas vary considerably. This diversity in the contexts encompasses the legal setting, the number of users, the costs of monitoring these uses, the means available to public organisations in charge of water resource management, the available information on groundwater resources, etc. Consider the huge difference between the case of a small group of large-scale groundwater users in California, whose direct negotiations receive technical support from state services, and the Indus plain, where public authorities with limited means face millions of small-scale farmers using unregistered wells and boreholes.

Since the mid-1960s, many authors have studied the institutions established to access and possibly to manage the use of this resource. Among these studies, two approaches stand out as being particularly well-structured: the "Groundwater governance as collective action" approach, which developed its analyses around the figure of E. Ostrom and the analysis made by T. Shah of informal groundwater economies. A third group of authors (A. Prakash, A. Mukherji and T. Birkenholtz) do not form per se a school of thought but they share many commonalities in their studies of groundwater governance, in particular the use of a political ecology approach. While the analytic frameworks developed by these approaches were designed in specific contexts, the two first later matured into broader theories, aiming at covering a much larger set of situations.

The three approaches share their willingness to analyse and understand situations of groundwater governance. However, few papers have identified links between these approaches. When such connections were made (e.g., Mukerji and Shah, 2005; Schlager, 2007), the authors rarely made an explicit comparison of the analytical frameworks and main theses nor did they position them face to face. At first sight, the approaches may appear disconnected and even to produce contradictory results. The aim of this article is to engage an exchange between the three approaches, through a comparative analysis of their main heuristic viewpoints, research programmes, results and theses.

Here we make use of the concept of governance, even though its use for the analysis of natural resource management precedes the earliest works cited here. However, the ideas that this concept conveys have been debated and applied in surface and groundwater studies for many years. In fact, this concept is close to what V. Ostrom (1971) referred to as "institutional arrangements". Governance refers here to the wide spectrum of forms of coordination between actors for allocating and managing resources that goes beyond the dichotomy between market and state. 


\section{THREE DISTINCT READINGS OF GROUNDWATER GOVERNANCE}

Groundwater governance as collective action: understanding the performance and robustness of institutions

E. Ostrom is mostly known for her analysis of the governance of common pool resources. The international recognition of her works is mainly linked to the methodological approach she helped develop at the University of Indiana in the framework of the "Workshop in Political Theory and Policy Analysis" (the so called "Bloomington school", Aligica and Boettke, 2009). Much less known is the fact that, at the beginning of her career, she studied groundwater management in southern California.

Indeed, during her PhD in political science (Ostrom, 1965), she tried to understand the emergence of institutional arrangements made to govern a groundwater basin ${ }^{1}$ in the Los Angeles metropolitan area facing increasing salt water intrusion. She described the process of emergence of public enterprises designed to manage this issue and to provide related public goods and services. She also stressed the role of public entrepreneurs in the process. Whereas private entrepreneurs are free to follow their interests and to make a profit in a market-based system, the capacity of involvement of public entrepreneurs depends, more fundamentally, on the political system in which they operate, i.e., the set of rules that organizes life in society. Moreover, she explained the way institutional arrangements were negotiated between the stakeholders, and the technical and economic solutions which were suggested and implemented to pursue the development of the metropolitan area, in the context of risks generated by water scarcity.

Thus, even if she did not refer to the debates, which were underway at that time concerning collective action ${ }^{2}$ or governance, she already insisted on the capacity of self-organisation of groups created to collectively manage a common problem. During the same period, Weschler (1968) was also working on groundwater management, in the same geographical area, but in different groundwater basins. He showed that different management solutions had been found by actors in situations that appeared to be quite analogous in climatic and organisational terms. Fifteen years later, this assessment of such a wide range of locally crafted institutions led Ostrom to ask W. Blomquist to make a detailed analysis of the management of four groundwater basins located in southern California. The aim was to analyse the way institutions were built and to understand the factors which influenced the variety of institutional responses, in quite similar situations (Blomquist, 1987). Another important point of Blomquist's work was to understand why many of these institutions had survived, i.e., the factors that contributed to the success and longevity of these institutions.

The analysis was later expanded to four other groundwater basins in California (Blomquist, 1992). In almost all, local actors managed to draw up rules to ensure that groundwater uses matched recharge, and, in the case of coastal aquifers, prevented salt intrusion. Despite a wide range of negotiation processes and the variety of their outcomes in terms of management rules, these cases shared similar characteristics, such as their polycentrism and local control over groundwater governance. The performance of the management rules designed by groundwater users was assessed using three criteria: effectiveness, adaptability and equity. Only one of the cases analyzed

\footnotetext{
${ }^{1}$ Groundwater basin, aquifer and aquifer system will be used in this paper as synonymous.

${ }^{2}$ The book by Mancur Olson (1965) was published during the same period.
} 
by Blomquist was clearly a failure, whereas the others cases studied could more or less be considered as performing with regards to these criteria.

This initial work was later followed, with some evolution in the research programme. Blomquist et al. (2004) assessed the legal frameworks, the judiciary decisions, and the collective actions for groundwater governance in the southwestern United States. They paid specific attention to the way institutional processes enable the conjunctive use and management of groundwater and surface water resources. More recently, Steed (2010) assessed the factors involved in the stability and evolution of the institutions for groundwater governance since the 1930s in some of the basins formerly studied by Blomquist.

Ostrom often argued that using case-specific combinations of analytical methods would be more effective than attempting to devise a single method that would be relevant in all situations (Poteete et al., 2010). While pragmatism is thus acknowledged, the Bloomington school progressively stabilized a heuristic method at the interface between public economy (especially the public choice approach) and an institutional analysis built around the Institutional Analysis and Development framework (Aligica and Boettke, 2009). More recent developments of the Bloomington School research programme give more importance to the analysis of social ecological systems and of the factors which contribute to the performance and the robustness of the institutions (Steed, 2010). Robustness of a system refers to the maintenance of the performance of this system despite internal stress or external disturbance (Anderies et al., 2004). "Robust institutions (...) allow for changes in rules to respond to shocks, newly perceived threats, or changes in design objectives" (Steed, 2010: 26).

The original case studies were the first on a list that subsequently became much longer and concerned many more different types of common pool resources, to inform the general research programme of the Bloomington school. One of the goals of the programme was to define conditions under which common pool resource users are likely to set up sustainable management of these resources. This programme led to theses about the principles on which long-enduring rules for usermanaged common pool resources are generally based (Ostrom, 1990), as well as the conditions regarding the resource and the users' characteristics which provide a favourable context to draw up such rules (Ostrom et al., 2000). Other analyses of cases involving users in groundwater governance later used these theses. Ross and Martinez-Santos (2010) found that the principles for user-based management rules provided a valuable insight of complex systems involving both users and the administration for the governance of aquifers in Australia and Spain. Lopez-Gunn and MartinezCortina (2006) used the conditions regarding users' characteristics to understand the performance of groundwater user associations in Spain and added to these conditions others on the attributes of higher-level authorities.

\section{Dynamics of informal groundwater economies: opportunities for practical policies}

T. Shah originally analysed the potential of informal groundwater markets for regional economic development in India (Shah and Raju, 1988). Later on, he expanded his analysis to the co-evolution of the economy created by intensive agricultural groundwater use and groundwater resources in South Asia. He revealed the extremely important role groundwater now plays in South Asian rural areas, but also the increasing fragility of these groundwater economies (Shah et al., 2003).

Shah's main thesis is that governance systems used for South Asian aquifers are not ripe for the Integrated Water Resources Management (IWRM) approach (Shah, 2009). Indeed, the three important pillars of the IWRM approach, namely water policy, law, administration, are currently not implementable, and consequently, the tools developed in such approaches are simply not practicable. For instance, the transaction costs of registering thousands of small-scale farmers would 
be simply too high. Instead of continuing to try to implement a governance system based on IWRM principles, policies makers should be more pragmatic and look for mechanisms that account for the informality of the groundwater economies from the outset. These pragmatic approaches could be defined based on typologies of groundwater economies, particularly the characteristics of the aquifers. While groundwater recharge programmes are successful in hard rock aquifers, approaches based on more indirect demand management could be used in alluvial aquifers (Shah, 2012). An interesting example of such an approach is the Jyotirgram system in Gujarat, where the state set up a specific electrical network for agricultural water use, that meant water use could be controlled through the power supply. Shah et al. (2008) judged such initiatives to be successful in indirectly controlling water use while not harming the groundwater economy, thanks to an increase in the reliability of power supply.

Shah later extended his research to other countries and in particular to comparisons with Mexico (Scott and Shah, 2004), China and Spain (Mukherji and Shah, 2005). Shah et al. (2007) proposed a worldwide assessment of groundwater use and management based on this conceptual and methodological construct, leading to a general typology of groundwater economies. While Shah stands as the core author of such an approach, other authors including Moench (2007) share his assessment that direct implementation of the formal management tools from the IWRM toolbox is not the best way to tackle groundwater overuse in developing countries.

\section{Political ecology of groundwater}

Here we bring together three authors: A. Prakash (2005), A. Mukherji (2006) and T. Birkenholtz (2009). Although they do not form a well-structured school of thought, their heuristic methods share many commonalities, and in particular they all draw much on political ecology, as proposed by Greenberg and Park (1994). Their approaches are also affiliated with Marxist political economy (Mollinga, 2010) and with Foucauldian analyses of power.

The authors analysed aquifers which are intensively used for irrigation in India. The core focus of their work was to study groundwater as a contested resource within social and political arenas, both at village and state levels. First, they analysed the diversity of actors' interests and resources, of the power relations, and of possible coalitions among actors. Second, they assessed the way groundwater governance (from farmer-to-farmer agreements to public policies) is designed, legitimized, implemented and possibly contested. Third, the consequences of farmers' different abilities to access groundwater on their choices and on differentiation among farms were analysed.

Prakash (2005) studied social differentiation as a consequence of groundwater overdraft in a village in Gujarat. He argued that decreasing water availability in the boreholes led to further differentiation between farmers, since the richest farmers, who were shareholders of collective boreholes, stopped selling surplus water to poorer farmers, who were thus compelled to farm on the richer farmers' land under conditions that were unfavourable for them. In such conditions, supporting increased development of water transactions between farmers (for instance by setting up a low flat electricity tariff for water) may help reinforce the skewed distribution of the added value. Mukherji (2006) analysed the design and implementation of groundwater governance policies in West Bengal and Gujarat. The structure and power of farmers' organisations and the political history of each state led to a situation in which there was no regulation of groundwater use in Gujarat, where groundwater was overexploited, whereas strict regulations were enforced in West Bengal, where only limited groundwater overdraft had been diagnosed. Finally, Birkenholtz (2009) analysed an institutional groundwater reform in Rajasthan. The aim of the reform, which was encouraged by the World Bank, was to establish stricter regulations and individual property rights. The government of Rajasthan attempted to convince farmers of the relevance of the reform. Elite farmers generally agreed with the reform, particularly because they thought they could influence local groundwater regulatory 
bodies. By contrast, grassroots farmers were likely to see further limits imposed on their water use, while not having a voice in future decision-making on groundwater governance.

All these studies identified flaws in several groundwater governance policies, such as regulation and water markets, which are widely considered to be good practices. The authors proposed limited and different - arguments for improved groundwater governance. Birkenholtz (2009) argued that, to counter the top-down implementation of regulations for groundwater use, bottom-up accountable institutions could give more voice to marginalised farmers. By contrast, Mukherji (2006) considered that strong farmer organisations, at least like those that exist in Gujarat, did not help find solutions for the sustainable use of groundwater.

\section{COMPARING THE READINGS IN TERMS OF METHODS AND RESULTS}

Our comparison of the approaches is structured in terms of the original cases studied, the components of the governance system that were analysed, the domain of validity of each approach, the heuristic methods and the suggested implications of the research results. To facilitate the comparison, the three approaches are summarized in Table 1.

\section{The structuring role of the original case studies}

Even though two of the three approaches were used worldwide, the analytical frameworks and research objects were initially based on in-depth investigations of specific case studies taking place in quite different contexts. First, the authors of the Bloomington School built their analysis in the southwestern United States, where many (mainly urban) groundwater users are able and willing to participate in designing groundwater management rules. Moreover, the Californian and federal administrations provided support for negotiations in the form of hydrogeological data, generally accepted locally designed agreements and monitored implementation of agreed upon rules. In contrast, South Asia, where the two other approaches were built, is characterised by numerous informal small-scale (mainly rural) groundwater users who have no voice in the decision-making process, public authorities who have not the capacity to directly monitor groundwater uses, and most of the time, a very weak de facto enforcement of legal regulations. Moreover, in South Asia, the power inequalities between the farmers themselves, and between farmers and the local elite and the state administration, are much larger than in California. These differences in the original case studies played a key role in the differences in the analysed components of effective governance and in the heuristic methods chosen.

\section{Different elements analysed to achieve effective governance}

The Bloomington school and Shah agree on the least that what can be expected from governance is that the aquifer should not be overused ${ }^{3}$. We denote governance systems that enable such sustainable use as "effective". The authors making use of political ecology generally do not provide a definition of effective governance, because the outcomes of the social processes they study are usually not compared with a situation of reference. The aim of their approach is more to deconstruct the proposed solutions. Thus, these authors focus more on understanding failures to reach effective governance.

\footnotetext{
${ }^{3}$ A detailed discussion of the relevance of the overexploitation concept is beyond the scope of this paper (see Custodio, 2006).
} 


\begin{tabular}{|c|c|c|c|}
\hline & $\begin{array}{l}\text { Groundwater governance } \\
\text { as collective action }\end{array}$ & $\begin{array}{l}\text { Dynamics of informal } \\
\text { groundwater economies: } \\
\text { opportunities for practical } \\
\text { policies }\end{array}$ & $\begin{array}{l}\text { Political ecology of } \\
\text { groundwater }\end{array}$ \\
\hline $\begin{array}{l}\text { Geographical location of } \\
\text { the initial analysis }\end{array}$ & Southern California & South Asia & India \\
\hline $\begin{array}{l}\text { Some case studies for } \\
\text { which the analytical } \\
\text { framework was later used }\end{array}$ & $\begin{array}{l}\text { U.S. (Arizona, Colorado, } \\
\text { Oregon), Australia, Spain }\end{array}$ & Mexico, China & \\
\hline Focus of the analysis & \multicolumn{2}{|c|}{$\begin{array}{l}\text { The links between the characteristics of the resource- } \\
\text { actors system and the outcomes in terms of governance }\end{array}$} & $\begin{array}{l}\text { The process through which } \\
\text { governance is set up }\end{array}$ \\
\hline Main subject of study & $\begin{array}{l}\text { Institutional development: } \\
\text { Collective action and rules } \\
\text { for self-governing aquifer } \\
\text { systems }\end{array}$ & Groundwater economy & Political coalitions \\
\hline Method of analysis & $\begin{array}{l}\text { Many cases, in order to } \\
\text { extract generic theses } \\
\text { which explain the } \\
\text { performance and } \\
\text { robustness of institutions }\end{array}$ & $\begin{array}{l}\text { Many cases, in order to } \\
\text { produce typologies of } \\
\text { situations }\end{array}$ & $\begin{array}{l}\text { Case study approaches. } \\
\text { Sometimes comparison, } \\
\text { but no attempts at } \\
\text { generalisation }\end{array}$ \\
\hline $\begin{array}{l}\text { Elements studied to } \\
\text { account for how } \\
\text { governance is achieved }\end{array}$ & $\begin{array}{l}\text { Management rules and } \\
\text { characteristics of the } \\
\text { resource and the actors } \\
\text { which increase the } \\
\text { likelihood of cooperation } \\
\text { between users }\end{array}$ & $\begin{array}{l}\text { Role of informal and local } \\
\text { institutions (water } \\
\text { markets, groundwater } \\
\text { recharge movements) }\end{array}$ & $\begin{array}{l}\text { Governance as a case- } \\
\text { specific result of } \\
\text { coalitions of actors }\end{array}$ \\
\hline $\begin{array}{l}\text { Main principles behind } \\
\text { the institutional design to } \\
\text { achieve effective } \\
\text { governance }\end{array}$ & $\begin{array}{l}\text { Polycentricity and } \\
\text { involvement of users in } \\
\text { groundwater management } \\
\text { Principles that rules used } \\
\text { in enduring self-organized } \\
\text { governance systems are } \\
\text { likely to be based on }\end{array}$ & $\begin{array}{l}\text { Opportunities for } \\
\text { pragmatic and indirect } \\
\text { approaches }\end{array}$ & $\begin{array}{l}\text { No attempt to define } \\
\text { "effective governance" }\end{array}$ \\
\hline $\begin{array}{l}\text { Proposed use of these } \\
\text { theses to support } \\
\text { effective groundwater } \\
\text { governance }\end{array}$ & $\begin{array}{l}\text { Understanding the } \\
\text { obstacles that have to be } \\
\text { removed to implement } \\
\text { sustainable self-governing } \\
\text { management }\end{array}$ & $\begin{array}{l}\text { Defining relevant } \\
\text { management objectives and } \\
\text { approaches which depend } \\
\text { on the original } \\
\text { characteristics and } \\
\text { constraints }\end{array}$ & $\begin{array}{l}\text { Generally not an objective } \\
\text { of the research }\end{array}$ \\
\hline
\end{tabular}


Where the Bloomington school and Shah differ is in the main elements they consider to ensure effective governance, in particular: i) the participation of water users and ii) tools for demand management. Ostrom (1990) gave special importance to the participation of water users and argued that common-pool resource users should take part in the design of management rules, against theories advocating state management or privatisation ${ }^{4}$. And indeed, three out of the four aquifer management cases she reviewed showed that such participation enabled sustainable long-term use of the aquifer. In the cases she reviewed, governance involved the formally defined regulation of water uses and especially control of individual water consumption. Apart from showing that their costs were reasonable in the local context, she did not conduct an in-depth analysis of the management tools used, since they were not a hotly debated issue. In a sense, Ostrom's analysis is focused on the conditions of the design of a governance system for groundwater resources that involves users in the decision-making. Schlager confirmed this position when she claimed that "a growing body of groundwater case studies demonstrates that groundwater users are capable of devising solutions to common pool resource dilemmas that are local in nature." (Schlager, 2007: 149). Constraints were analysed to see how they could be overcome to reach participatory management involving direct demand management. Ostrom also looked (followed later by Blomquist, 1992, and Steed, 2010) at the performance of the institutions that were created. Thus, even if the Bloomington school does not look at the efficiency of the governance structures (in the economic sense of the term), it is interested in the performance and robustness of institutions governed by water users.

Shah (2009), on the other hand, focused on the tools for demand management and paid particular attention to management tools that are (in)compatible with the informality of groundwater uses. The way he took initial constraints into account is thus radically different from the Bloomington school's approach: Shah started from the analysis of the constraints that prevent effective governance of groundwater - in the sense of using the IWRM toolkit (Shah, 2009), and then considered what could be done. Given that many constraints may not be removed, at least in the short term, in South Asia, governance systems should be designed to adapt to these constraints. Incidentally, he considered that farmers are often not interested or able to play a prominent role in monitoring groundwater uses, and gave a bleak account of attempts to let farmers control their own water uses in both developed and developing countries.

\section{Increasing overlap in the proposed "domains of validity"}

Both Ostrom and Shah acknowledged that other approaches may be valid in contexts that differ from those they investigated in their original analyses. Nevertheless, they also used their analytical framework in much broader contexts than was originally the case, leading to an increasing overlap in the proposed "domains of validity" of the three approaches. Such overlap is expected to increase because the number of cases of groundwater governance involving some form of user participation is also likely to increase. In contrast, the three authors inspired by political ecology were focused on groundwater governance in India. While political ecology was also used to study aquifers in other countries, there has been no attempt of generalisation. This increasing overlap leads to two major differences in the readings of cases of groundwater governance.

\footnotetext{
${ }^{4}$ The Bloomington school did not compare the efficiency between groundwater governance systems where users are involved and where they are not. They undertook such analysis on irrigation systems whose results were favourable to users' involvement (Lam, 1998).
} 
First, Shah (2009) acknowledged that formalized groundwater governance can succeed in developed countries, but pointed out that the results of initiatives for regulation of groundwater uses in the developed countries concerned were at best lukewarm. In particular, while Ostrom (1990) considered that the governance systems set up in California had proved their capacity to ensure sustainable use of the aquifers (an analysis confirmed by Steed, 2010), Shah argued that the aquifers were much better protected by supply management than by actual regulation of groundwater uses, and that these aquifers are islands of management in a sea of open access situations in all aquifers in south-western California.

Second, Ostrom (1990) claimed that her approach was not applicable in large-scale common-pool resource where there is no communication between users. This said, later on, she applied her approach to larger commons. Even though she did not work on aquifers in developing countries, she worked on global commons, such as climate change, which shows similarities with these aquifers in the absence of strong organisations able to enforce agreements and the high cost of enforcing regulations. She generally used the same approach, which involves attempting to limit free rider behaviours and building up polycentric governance systems, where users of the global commons remain actors at the lower levels of nested institutions (Ostrom, 2010). These two proposals are in stark contrast with that of Shah concerning relevant governance of informal groundwater economies.

\section{Convergences and divergences in heuristic approaches}

First, the approaches differ in terms of the contour of the system analysed. In the Bloomington school, the system considered is the water sector at large, taking into account surface and groundwater, quality and quantity issues, short term and long term, the wide range of stakeholders, etc. (an approach which is not so far from IWRM approaches). The two other approaches take a broader perspective, with, for instance, the inclusion of the energy-irrigation nexus or the local political scene, in that sense shifting from a "watershed" to a "problemshed" definition of the system (Mollinga et al., 2007).

Second, the research programmes of Shah and of the Bloomington school are firmly anchored in institutional analysis and new institutional economics. Both aim at identifying certain regularities in the relation between the initial characteristics of the resources and the actors on the one hand, and the outcomes in terms of governance on the other. They attempt to achieve this by studying large sets of case studies. The three approaches also share an explicit interest in path dependency, but with very different definitions of the concept. The three authors drawing on political ecology focus on the way the negotiation processes lead to case-specific results, and states that the characteristics of the aquifer are not so important. As Mukherji (2006: 393) pointed out: "groundwater-related policies in India have very little to do with the scarcity, depletion or quality of groundwater, and more to do with rural politics manifested, among other things, in terms of the presence or absence of farmer lobbies". It thus takes a position explicitly opposed to the above-mentioned ambitions of the two other research programmes. The Bloomington school also gives importance to path dependency (Blomquist, 1992; Steed, 2010) as a factor which explains the creation and sustainability of institutions to govern groundwater. Steed (2010) stated that institutional change is rather difficult to achieve, because of the weight of culture and informal institutions and because of the transaction costs it generates. Shah (2009) pointed to the weight of path dependency, but more from a longterm perspective and considering the narratives used for groundwater governance, and not so much on the processes used to design groundwater governance in specific cases.

Third, Shah and the three authors inspired by political ecology place much more importance on power relationships in groundwater governance than the Bloomington school. Moreover, the authors of the political ecology approach often use the Foucauldian concept of governmentality, i.e., 
the state attempts to "conduct the conducts". In particular, Birkenholtz (2009) studied the way the state aimed to influence groundwater use by influencing the ideas being debated and the behavioural norms concerning groundwater use. The interest paid by Shah to indirect management tools brings his approach surprisingly close to this concept of governmentality. Indeed, in a context where direct demand management is not possible, he looked at ways to indirectly influence the behaviours of farmers. The difference lies in the fact that the political approach places more importance on political or cognitive ways of influencing behaviours, while Shah focuses more on economic means. Such interest in governmentality is in stark contrast with the Bloomington school's approach in which water users are invited to directly participate in the design of governance. Finally, Shah and the authors using the political ecology approach have studied much more than the Bloomington school what happens when governance fails, but with a difference: Shah looked at the evolution of the groundwater economy at territorial level, while authors using political ecology paid more attention to the impacts of the groundwater crisis at household and village levels.

\section{Contrasted proposals for supporting effective governance}

Both Ostrom's and Shah's approaches claimed to seek to link academic studies with more practical reflections (something that authors drawing on political ecology generally refrained from doing). However, their heuristic methods and research results led to differing theses on the components of effective governance and how to achieve it. In particular, both approaches cited the success stories they identified in their original case studies. Ostrom considered that resource users need to be fully involved in the definition of rules, and that the main role of the state should be the one played by the US Geological Survey in the design of south-western California groundwater basin governance, which was to facilitate and provide information to users so that they can reach agreement (1992). Ostrom's criteria for rules for long-enduring systems have indeed reached a much wider audience than the academic community (WRD, 2009). By contrast, Shah (2009) called for the use of more indirect management tools and for attention to be paid to locally build informal institutions for groundwater access and management. It is important to make it clear that Shah criticizes traditional and formalist ways of implementing demand management, both in terms of the tools used and of the expectations that handing the issue to groundwater users will be sufficient for demand management to take place. Shah does not criticize involvement of groundwater users in the design of governance systems (even though it is not the focus of his analyses), as long as these users are not expected to participate in the implementation of these governance systems. As mentioned above, the question of the implementation of an effective governance system to manage groundwater is not the ambition of the group of scholars drawing on political ecology.

\section{CONCLUSIONS AND PERSPECTIVES}

The issue of groundwater governance has given birth to very rich and diverse analytical frameworks. The analysis we have undertaken here stresses the importance of the aquifers each author originally used to build his/her analysis. Since two of the approaches aimed to reach a wider audience, the historical link between the original cases studied and later broader framework needs to be made explicit so that other scholars who wish to use these frameworks understand the origin and rationale of each heuristic method.

While the Bloomington school and Shah converge on the need for joint involvement of the various stakeholders in the design of groundwater governance, they clearly differ on the components of governance systems required to achieve sustainable groundwater use, and especially the benefits of involving users in the implementation of the governance systems. For that reason, and more importantly, they differ on what should be the focus of academic analyses. It may be thus of interest 
to organize joint "readings" of groundwater governance, seen not so much as analytical results, but rather as processes to understand local situations. It would also be useful to discuss the content of research programs that enable fruitful reading of situations of groundwater governance based on local specificities. This could concern the choice of criteria to be analysed for assessing effective governance and those that influence the achievement of effective governance.

These approaches have already evolved and will probably continue to do so, both in terms of the topics addressed and in terms of their analytical stand. With regards to the topics, all three approaches were historically based on quantitative aspects of groundwater governance. In Europe, groundwater overdraft problems have sometimes produced innovative solutions (e.g., Petit, 2009), but the issue of groundwater quality acquires increasing importance, and the indirect management approaches advocated by Shah will probably play a useful role in the management of agricultural pollution. Regarding the analytical stand, the notion of "adaptive management" of the governance system plays an increasingly important role in the analyses of the Bloomington school and Shah. The concept of adaptability, proposed by Blomquist (1992) as one of the performance indicators, is of fundamental importance in recent analyses of robust institutions (Blomquist and Ostrom, 2008; Steed, 2010). This idea echoes Shah's assessment (2009: 209): "Transforming chaos into stability may prove impossible, but transforming inhumane anarchy into humane anarchy through adaptive approaches may be well within the realm of possibility". Thus, studying the resilience of a groundwater territory, defined as a social ecological system, and assessing the adaptive nature of the governance processes implemented, is one of the issues that would probably benefit from a crossreading of the authors studied here.

While scholars have long showed an interest in groundwater governance of specific cases, the worldwide development of groundwater use has, by and large, been a "silent revolution" (LopezGunn and Llamas, 2008). The situation is now changing in both developed and developing countries: in recent years, many management experiments have been conducted in new groundwater governance contexts which are not exactly the same as the cases on which the three approaches were historically built. Therefore, as much as there is an interest for more dynamic exchanges between authors using different approaches, it would be useful to increase documentation of the many on-going experiments around the world, to continue and strengthen the two-way link between theories and case study analyses, which is a core element in the interest and success of the three approaches analysed in this paper.

\section{ACKNOWLEDGMENTS}

The authors wish to thank F. Aguilera-Klink, O. Aubriot, M. Kuper, E. Ostrom, T. Shah and two anonymous reviewers for their reading and comments on initial versions of the paper.

\section{REFERENCES}

Aligica PD, Boettke PJ. 2009. Challenging Institutional Analysis and Development: The Bloomington School. London: Routledge.

Anderies JM, Janssen MA, Ostrom E. 2004. A framework to analyze the robustness of socialecological systems from an institutional perspective. Ecology and Society 9(1): 18. [online] URL: http://www.ecologyandsociety.org/vol9/iss1/art18/

Birkenholtz T. 2009. Groundwater governmentality: hegemony and technologies of resistance in Rajasthan's (India) groundwater governance. The Geographical Journal 175(3): 208-220. 
Blomquist W. 1987. Getting Out of the Trap: Changing an Endangered Commons to a Managed Commons, $\mathrm{PhD}$ dissertation, Bloomington, Indiana University.

Blomquist W. 1992. Dividing the Waters. Governing Groundwater in Southern California, San Francisco, California: ICS Press.

Blomquist W, Ostrom E. 2008. Deliberation, learning, and institutional change: the evolution of institutions in judicial settings. Constitutional Political Economy 19(3): 180-202.

Blomquist W, Schlager E, Heikkila T. 2004. Common Waters, Diverging Streams: Linking Institutions and Water Management in Arizona, California, and Colorado, Washington D.C.: Resources for the Future Press.

Custodio E. 2006. Aquifer overexploitation: what does it mean? Hydrogeology Journal 10: 254-277.

Greenberg JB, Park T. 1994. Political ecology. Journal of Political Ecology 1: 1-12.

Lam WF. 1998. Governing Irrigation Systems in Nepal: Institutions, Infrastructure, and Collective Action. Oakland, CA: ICS.

Lopez-Gunn E, Llamas MR. 2008. Re-thinking water scarcity: Can science and technology solve the global water crisis? Natural Resources Forum 32: 228-238.

Lopez-Gunn E, Martinez-Cortina L. 2006. Is self-regulation a myth? Case study on Spanish groundwater user associations and the role of higher-level authorities. Hydrogeology Journal 14: 361379.

Moench M. 2007. When the well runs dry but livelihood continues: adaptive responses to groundwater depletion and strategies for mitigating the associated impacts. In The Agricultural Groundwater Revolution: Opportunities and Threats to Development, Giordano M, Villholth KG (eds). CABI Head Office: Oxford, UK: 173-192.

Mollinga P. 2010. The Material Conditions of a Polarized Discourse: Clamours and Silences in Critical Analysis of Agricultural Water Use in India. Journal of Agrarian Change 10(3): 414-436.

Mollinga P, Meinzen-Dick R, Merrey D. 2007. Politics, Plurality and Problemsheds: A Strategic Approach for Reform of Agricultural Water Management. Development Policy Review 25(6): 699719.

Mukherji A. 2006. Political ecology of groundwater: the contrasting case of water-abundant West Bengal and water-scarce Gujarat, India. Hydrogeology Journal 14: 392-406.

Mukherji A, Shah T. 2005. Groundwater socio-ecology and governance: a review of institutions and policies in selected countries. Hydrogeology Journal 13:328-345.

Olson M. 1965. The Logics of Collective Action: Public Goods and the Theory of Groups. New York: Schoken Books.

Ostrom E. 1965. Public Entrepreneurship: A Case Study in Ground Water Basin Management, PhD Dissertation, University of California, Los Angeles.

Ostrom E. 1990. Governing the Commons. The Evolution of Institutions for Collective Action, Cambridge, Cambridge University Press.

Ostrom E. 2000. Reformulating the commons. Swiss Political Science Review 6(1): 29-52. 
Ostrom E. 2007. Collective Action and Local Development Processes. Sociologica (Italian Journal of Sociology) 3:1-32.

Ostrom E. 2010. Polycentric systems for coping with collective action and global environmental change. Global Environmental Change 20: 550-557.

Ostrom V. 1971. Institutional Arrangements for Water Resource Development. Report to the National Water Commission, Washington, DC.

Petit O. 2009. Un regard rétrospectif sur l'évolution de la gouvernance de l'irrigation en Beauce (1993-2008). Science et changements planétaires/Sécheresse 20(3) : 262-270.

Poteete AM, Janssen M, Ostrom E. 2010. Working Together: Collective Action, the Commons, and Multiple Methods in Practice. Princeton, NJ: Princeton University Press.

Prakash A. 2005. The dark zone: groundwater irrigation and water scarcity in Gujarat. PhD thesis submitted to Wageningan University, Wageningen, The Netherlands.

Ross A, Martinez-Santos P. 2010. The challenge of groundwater governance: case studies from Spain and Australia. Regional Environmental Change 10(4): 299-310.

Schlager E. 2007. Community management of groundwater. Giordano M, Villholth KG (eds). The Agricultural Groundwater Revolution: Opportunities and Threats to Development. Oxford, UK: CABI Publ: 131-152.

Scott CA, Shah T. 2004. Groundwater Overdraft Reduction through Agricultural Energy Policy: Insights from India and Mexico. Water Resources Development 20(2): 149-164.

Shah T, Raju KV. 1988. Working of groundwater markets in Andhra Pradesh and Gujarat: Results of two village studies. Economic and Political Weekly 26(3): 23-28.

Shah T. Roy AD, Qureshi AS, Wang J. 2003. Sustaining Asia's groundwater boom: An overview of issues and evidence. Natural Resource Forum 27: 130-141.

Shah T, Burke J, Villholth K. 2007. Groundwater: A global assessment of scale and significance. In: Molden, D. et al., Water for Food, Water for Life: A comprehensive assessment. London: IWMI/Earthscan.

Shah T, Bhatt S, Shah RK, Talati J. 2008. Groundwater governance through electricity supply management: Assessing an innovative intervention in Gujarat, western India. Agricultural water management 95(11): 1233-1242.

Shah T. 2009. Taming the anarchy. Groundwater governance in South Asia. Washington, D.C.: Resources for the Future Press.

Shah T. 2012. Community Response to Aquifer Development: Distinct Patterns in India's Alluvial and Hard rock Aquifer Areas. Irrigation and Drainage. This volume.

Steed B. 2010. Natural Forces, Human Choices: An Over Time Analysis of Responses to Ecological and Human Induced Disturbances in Southern California Water Basin Governance. PhD diss. Indiana University.

Weschler L. 1968. Water Resources Management: The Orange County Experience, California Government Series n ${ }^{\circ} 14$, Davis, University of California, Institute of Governmental Affairs. 
WRD - Water Replenishment District of Southern California. 2009. Nobel Laureate Dr. Elinor Ostrom Recognized 